研 究

\title{
キレート樹脂からのルテニウムー多孔性炭素複合材の開発とキャパシタ電極への応用
}

\author{
武藤 明徳, 田路 勇樹, Thallada Bhaskar, 阪田 祐作 \\ 岡山大学大学院自然科学研究科物質生命工学専攻, ₹ 700-8530 岡山市津島中 3-1-1
}

\section{Preparation of Ruthenium-Porous Carbon Composite from a Chelate Resin and Its Application to Capacitor Electrode}

\author{
Akinoiri Muto, Yuki Tohji, Thallada Bhaskar and Yusaku Sakata \\ Department of Applied Chemistry, Graduate School of Natural Science and Technology, Okayama University, \\ 3-1-1Tsushima Naka, Okayama 700-8530, Japan.
}

Received June 15, 2006

\begin{abstract}
SYNOPSIS
The ruthenium-porous carbon composites were prepared from a commercial chelate resin (IRC748) with the adsorption of aqueous ruthenium ion $\left(\mathrm{Ru}^{3+}\right)$ by carbonization $\left(\mathrm{N}_{2}\right)$ and activation $\left(\mathrm{CO}_{2}\right)$ at $800^{\circ} \mathrm{C}$. The specific surface area and pore volume of the composites depended on the amount of $\mathrm{Ru}^{3+}$ adsorbed on the chelate resin. The ruthenium ion changed to metallic ruthenium when the ruthenium content of the composite $\left(\mathrm{X}_{\mathrm{Ru}}\right)$ was below 10 mass\%. When $\mathrm{X}_{\mathrm{Ru}}$ was above 36 mass\%, not only metallic ruthenium but also ruthenium oxide $\left(\mathrm{RuO}_{2}\right)$ were found in the composite. The crystalline size of the ruthenium compounds from the Scherre equation were almost 30-33 $\mathrm{nm}$ by XRD analysis. The ruthenium-porous carbon composites were applied to electrode of capacitor. The specific capacitances $\left(\mathrm{C}_{S}\right)$ of the composite were stable in the charge and discharge experiment. The $\mathrm{C}_{S}$ depended on $\mathrm{X}_{\mathrm{Ru}}$; when $\mathrm{X}_{\mathrm{Ru}}$ was small $(0-30$ mass $\%)$, Cs deceased linearly with increasing $\mathrm{X}_{\mathrm{Ru}}$. However, $\mathrm{C}_{\mathrm{S}}$ increased with increasing $X_{\mathrm{Ru}}(>30$ mass $\%$ ). The effect of ruthenium content on the capacitance was also discussed by comparing the experimental results of physical mixing of porous carbon and ruthenium oxide.
\end{abstract}

KEY WORDS

porous carbon, ruthenium, composite, capacitor, chelate resin

1 緒言

電気二重層キャパシ夕は二次電池と比較して急速な充放電 が可能で, 繰返し充放電性能が優れる上, 化学反応を利用し ないという理由で寿命が長く使用温度範囲が広く, 新たな蓄 電デバイスとして利用され始めている”。 さらに広範な用途 で使用するためには静電容量の向上が重要で, 特に電極開発 の研究が盛んである. 炭素電極の細孔制御することによる電 気二重層の効率的な生成による静電容量の増大のほか, 高比 表面積の電極材料または電気伝導性重合体の電気収着 ${ }^{2}$ や, 金属酸化物など ${ }^{3)}$ の酸化還元過程と関連した擬似容量を利用 する方式 ${ }^{4)}$ がある．金属酸化物を用いる場合は活性炭と複合 化することが多い，例えば，ルテニウム化合物を用いたキャ パシ夕電極の研究には, ルテニウム種と炭素の混合材料を電 極とするものと,ルテニウム塩の水溶液を炭素多孔体に含浸 させて熱処理後, 電極とする方法が多く報告されている.こ のとき,ルテニウム化合物の微粒化, 炭素多孔体への高分散
化, および細孔表面から電解液側への露出など, 微細な構造 の制御が要求される.

筆者らは, 炭素前駆体としてのイオン交換樹脂に金属イオ ンを吸着させてから熱処理すると,金属イオンが金属もしくは 金属化合物に変換され(Metal Ion Exchanged Resin of Carbothemal Redaction: MIER-CTR法と略す), ナノ微粒子となって炭素質 に高分散することを見出している ${ }^{5}$. 本研究では MIER-CTR 法を用いてルテニウム一炭素複合材を調製し, キャパシタ電 極として評価した. また, 炭素多孔体と $\mathrm{RuO}_{2}$ の物理的混合物 をキャパシ夕電極として調製し，これと比較した.

\section{2 試料および実験方法}

\section{1 試薬および原料}

電極用炭素材料の原料には多価金属陽イオンの吸着に優れ ているイミノ二酷酸型キレート樹脂(オルガノ製; IRC748)を 用いた。特に 3 価の $\mathrm{Ru}^{3+}$ はキレート樹脂に強く吸着し, この 
ことは希薄な $\mathrm{Ru}^{3+}$ 水溶液を用いても溶液中の $\mathrm{Ru}^{3+}$ がほとんぞ なくなるまで樹脂に吸着されるので, 原料の調製に好都合で ある. Fig.1に Ru ${ }^{3+}$ が吸着した場合のイミノ二酢酸型キレート 樹脂の化学構造を示す.イミノ二酢酸のカルボキシル基の $\mathrm{H}^{+}$ (プロトン)と $\mathrm{Ru}^{3+}$ イオンがイオン交換され，イミノ構造に吸 着される. $\mathrm{Ru}^{3+}$ の吸着には塩化ルテニウム (III) 水和物 (和光 純薬製純度99.9\%)を用い, 蒸留後イオン交換操作により高純 度化した純水を実験に供した。

また,ルテニウムーカーボンの物理混合電極を作製する際 には，酸化ルテニウム (IV) 無水物 (和光純薬製 純度 $98 \%$ ) を 用いた. 硫酸(和光純葉工業株式会社 特級)を純水で 30 質量\% に希釈し，キャパシタの電解液として使用した。

\section{2 電極用炭素材料の調製}

イミノ二酢酸型キレート交換樹脂をカラムに充填し，塩酸 と食塩水を交互にカラムに流しコンディショニングを行った. $\mathrm{H}^{+}$型に変換後, 樹脂をカラムから取り出し, 室温にて風乾後 密栓できる容器内に保管した. この樹脂 $5 \mathrm{~g}$ に対し, 所定濃度 の塩化ルテニウム水溶液を $25 \mathrm{ml}$ 用い，樹脂が破砕しないよ うに䚓汼しながら平衡に至るように 48 時間回分接触を行っ た. 吸着操作後, 溶液中の $\mathrm{Ru}^{3+}$ の濃度を原子吸光光度計 (島 津製作所製 AA6200) を用いて決定し，物質収支関係からキ レート樹脂への $\mathrm{Ru}^{3+}$ の吸着量を求めた.

$\mathrm{Ru}^{3+}$ 吸着させたキレート樹脂を磁性ボートに平坦に広げ, 温度制御可能な電気炉中の石英管の中に設置し，Fig.2 (a) に 示す昇温パターンにより熱処理を行った. 昇温操作の途中で 空気気流中 $(300 \mathrm{cc} / \mathrm{min})$ で $350^{\circ} \mathrm{C}, 1$ 時間保持し，温度を上昇 に伴う樹脂の溶融を防止する処理 (不融化処理) を行った ${ }^{6}$. このようにして得た炭素材をさらに細孔構造を発達させるた め Fig.2 (b) に示す昇温パターンにより炭素材を $800^{\circ} \mathrm{C} て ゙ 20$ 分 間，二酸化炭素 (流量 $300 \mathrm{cc} / \mathrm{min}$ ) による賦活を行った.

2.3 炭素材料のキャラクタリゼーション

賦活物に含まれる金属化合物を XRD 測定装置 (Rigaku 製 $\mathrm{RAD}-2 \mathrm{R})$ を用いて粉末 $\mathrm{X}$ 線回折法により同定した。 また, XRD ピークの幅から Scherrerの式》)を用いて結晶子サイズを 算出測定した。
結晶子の大きさ $\mathrm{L}(\mathrm{nm})=\mathrm{K} \times \lambda /(\mathrm{B} \times \cos \theta)$

$\mathrm{K}:$ Scherrer 定数 $=0.9$

$\lambda$ : 使用 X 線管球の波長 $=1.54056 \AA(\mathrm{Cu}-\mathrm{K} \alpha)$

$\mathrm{B}$ : 半価幅

$\theta$ : 回折角

\section{4 賦活物中の Ru 含有量の評価}

$\mathrm{Ru}^{3+}$ を吸着させていないキレート樹脂の炭素材を熱重量測 定装置 (島津製作所製 TGA-51/51H)により灰化し，無機成分 の含有量を求めた。次に, $\mathrm{Ru}^{3+}$ を吸着させたキレート樹脂の 賦活物の灰分の含有量を同様に求め, 先に求めた $\mathrm{Ru}^{3+}$ を吸着 させていないで得た賦活物の無機成分の割合を差し引きし， ルテニウム含有量として算出した.

2.5 炭素材の比表面積および細孔構造の解析

調製した賦活物の比表面積および細孔分布は, 自動細孔構 造解析装置 (日本ベル製 BELSORP 28SP) を用いて $\mathrm{N}_{2}$ の吸脱

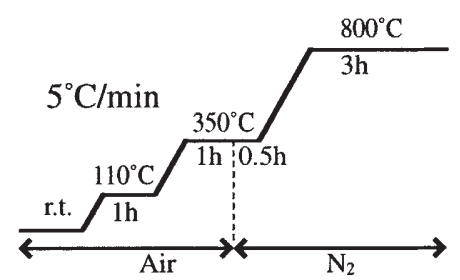

a) carbonization

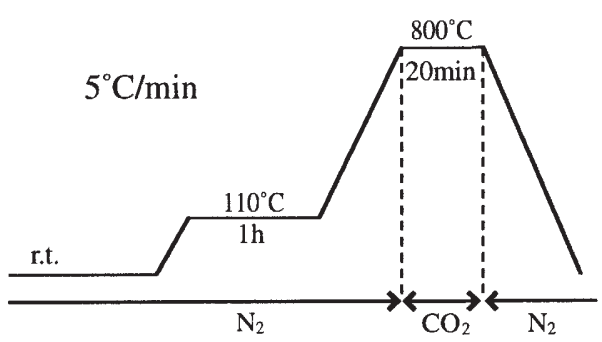

b) activation

Fig.2 Thermal treatment profile.

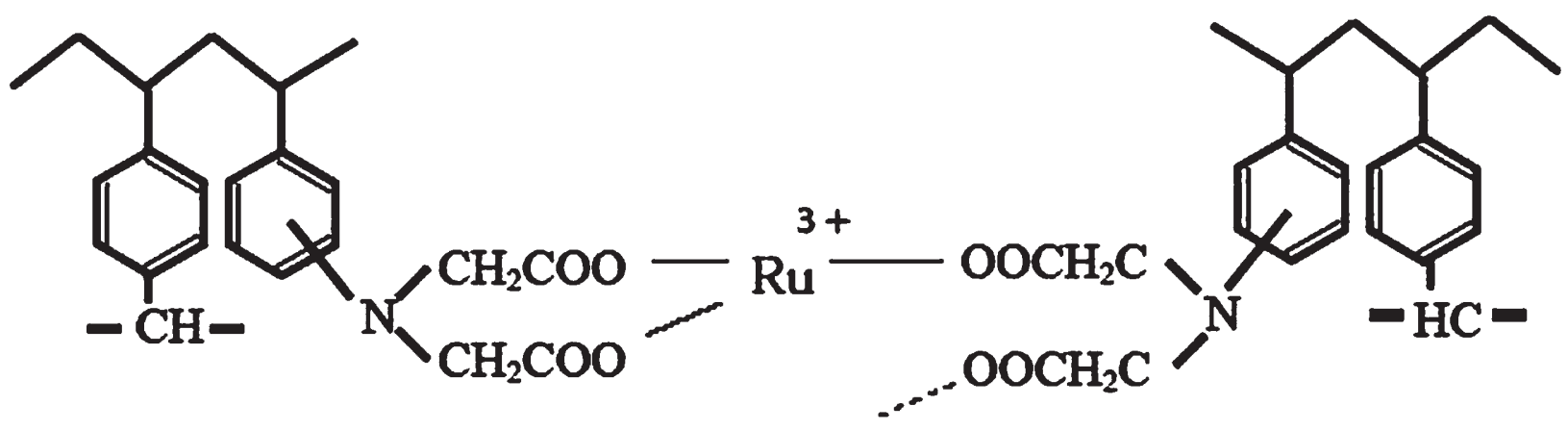

Fig.1 The chemical structure of imnodiacetate acid type clelate resin adsorbing $\mathrm{Ru}^{3+}$. 
着等温線から BET 法により比表面積を求め, DH + MP法より 細孔容積を求めた.

2.6 キャパシタの充放電特性評価

賦活物を $75 \mu \mathrm{m}$ 以下に粉砕し， $110^{\circ} \mathrm{C}$ で 24 時間大気中で乾 燥させた。これに電解液として $30 \mathrm{wt} \%$ 硫酸を加え, 減圧下に 30分保持し細孔内に電解液を十分浸透させスラリ一状の試料 を調製した.このスラリーを電極としてセパレーターを間に はさみ二極式セルを組み立てた ${ }^{8)}$. セルに充放電装置 (イン テック製)を接続し, $30^{\circ} \mathrm{C} に$ 保持した空気恒温槽中で充放電 操作を行った. 操作は $0 \mathrm{mV} ら 900 \mathrm{mV}$ まで定電流充電を行 い, 30 分間 $900 \mathrm{mV}$ で保持した後, $0.1 \mathrm{~mA}$ で定電流放電を行つ た. 静電容量は放電曲線から，電圧が 0.54 から $0.45 \mathrm{~V}$ に至る までの時間を求め, 次の式より算出した.

$$
\mathrm{C}=\mathrm{I} \times \Delta \mathrm{t} /\left(\left(\mathrm{V}_{1}-\mathrm{V}_{2}\right) \times \mathrm{m}\right)
$$

C: 炭素 $1 \mathrm{~g}$ あたりの静電容量 $[\mathrm{F} / \mathrm{g}], \mathrm{I}$ : 放電電流, $\mathrm{m}$ : 炭素材料の質量 $[\mathrm{g}]$,

$\Delta \mathrm{t}: \mathrm{V}_{2}$ から $\mathrm{V}_{1}$ まで電圧降下に要した時間 $[\mathrm{s}]$

\section{3 実験結果と考察}

$3.1 \mathrm{Ru}^{3+}$ のキレート樹脂への吸着等温線

室温 (約 $25^{\circ} \mathrm{C}$ ) にて回分接触法で求めた $\mathrm{Ru}^{3+}$ のキレート樹 脂への吸着等温線をFig.3に示す.一般に金属イオンがキレー 卜樹脂に吸着する場合, その吸着等温線はLangmuir式で相関 されることが多い. Fig.3の吸着等温線も明らかにLangmuir型 の等温線であり，式 (3)で相関できた.

$$
\mathrm{q}=\mathrm{QKC} /(1+\mathrm{KC})
$$

Q: 最大交換容量 $[\mathrm{mol} / \mathrm{g}], \mathrm{C}$ : 平衡濃度 $[\mathrm{mol}]$, q: 吸着量 $[\mathrm{mol}], \mathrm{K}$ : 定数

回分実験の結果を(3)式を相関させ, $Q=1.13 \mathrm{mmol} / \mathrm{g}, \mathrm{K}=205.8$ を得た。
これにより最大交換容量は1.13 mmol-Ru/g-resinとなるが,

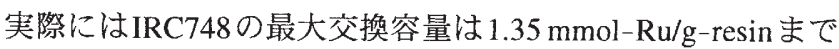
吸着した。水溶液中の $\mathrm{Ru}^{3+}$ は濃度が高くなると，例えば

$$
\mathrm{Ru}^{3+}+\mathrm{Cl}^{-}=[\mathrm{Ru} \cdot \mathrm{Cl}]^{2+}
$$

のように対イオンとイオン対と錯体を形成する可能性がある. また, 明確にイオン対を溶液中で形成しなくても, $\mathrm{Ru}^{3+}$ と $\mathrm{Cl}^{-}$ が同時にキレート樹脂中に浸透し, 結果として $[\mathrm{Ru} \cdot \mathrm{Cl}]^{2+}$ の形 でキレート基に吸着することも考えられ， $\mathrm{Ru}^{3+}$ 濃度の希薄な 場合と濃厚な場合は吸着機構が少し異なる可能性があり, 濃 度の高い領域で実測値と計算結果に差異が生じたと思われる。 しかし, 図中の実線は計算線であり実験結果とほぼ一致して おり, Langmuir式で相関することがキレート樹脂への $\mathrm{Ru}^{3+}$ の 吸着量を厳密に制御できることを意味しており, 炭素材料の 調製には極めて有利である.

3.2 賦活物のルテニウム含有量と細孔構造解析

種々のRu吸着量のキレート樹脂の各賦活物のルテニウム 含有量と比表面積および全細孔容積をTable 1 に示す. $\mathrm{Ru}^{3+}$ 吸 着量が多いほど賦活物中のルテニウム含有率は大きくなった. 賦活炭素物中のルテニウムの含有量は原料樹脂への吸着量に ほぼ比例することがわかった．さらにルテニウム含有量と BET比表面積および全細孔容積の関係をFig.4に示した. $\mathrm{Ru}^{3+}$ の吸着量が少なく, ルテニウムの含有量が小さいときは,ル テニウムの含有量が大きくになるにつれてBET比表面積およ び全細孔容積は減少する傾向にあった. これはルテニウム化 合物が炭素質ほど多孔性でなく, 質量として複合材に占める ほど細孔表面積や細孔容積の増大には笴与しないためと思わ れる. ただし, ルテニウム化合物の含有量が大きくなっても BET比表面積および全細孔容積がそれほど減少しなくなるの は, ルテニウム化合物の微粒子が一部, 二次粒子化して多孔 構造を形成している可能性もあり ${ }^{9,10)}$, 今後, 微細構造につい ては詳細に検討する必要がある。

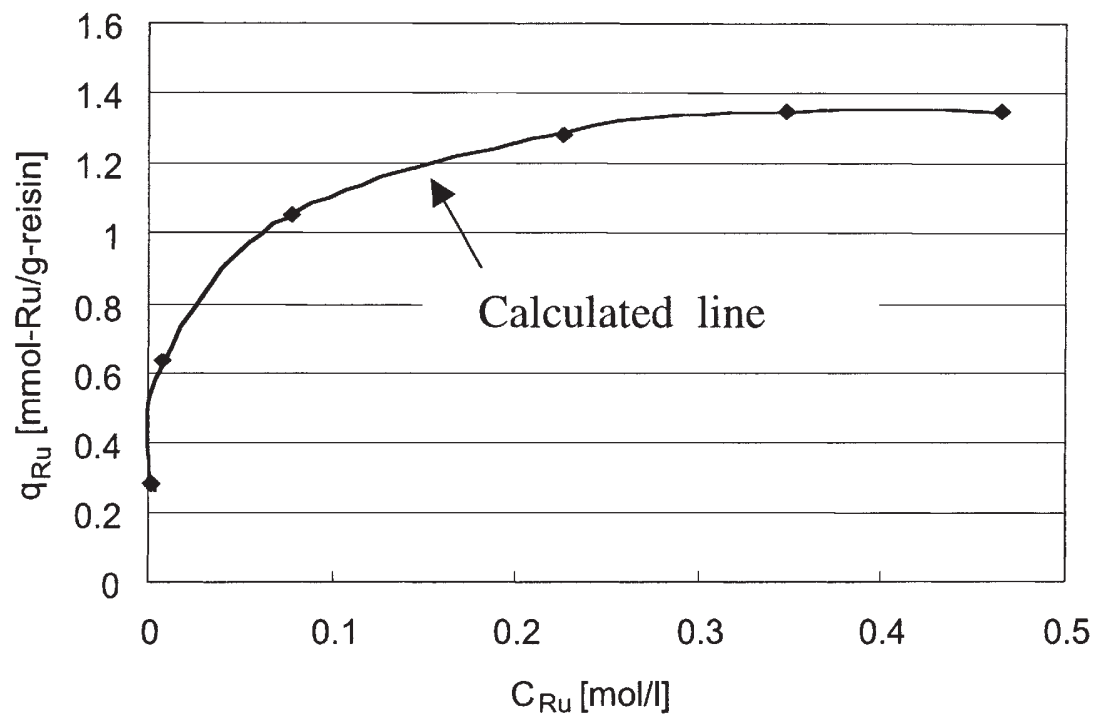

Fig.3 The adsorption isotherm of $\mathrm{Ru}^{3+}$ on IRC748. 
Table 1 Characterization of carbonaeous materials prepared from IRC748-Ru

\begin{tabular}{ccrc}
\hline $\begin{array}{c}\mathrm{q}_{\mathrm{Ru}} \\
{[\mathrm{mmol} / \mathrm{g}]}\end{array}$ & $\begin{array}{c}\text { Content of } \mathrm{Ru} \\
{[\mathrm{mass} \%]}\end{array}$ & $\begin{array}{c}\mathrm{S}_{\mathrm{BET}} \\
{\left[\mathrm{m}^{2} / \mathrm{g}\right]}\end{array}$ & $\begin{array}{c}\mathrm{V}_{\mathrm{p}} \\
{\left[\mathrm{mm}^{3} / \mathrm{g}\right]}\end{array}$ \\
\hline 0 & 0 & 640 & 380 \\
0.281 & 10 & 470 & 310 \\
0.635 & 19 & 370 & 250 \\
1.06 & 36 & 340 & 260 \\
1.35 & 53 & 370 & 260 \\
\hline
\end{tabular}

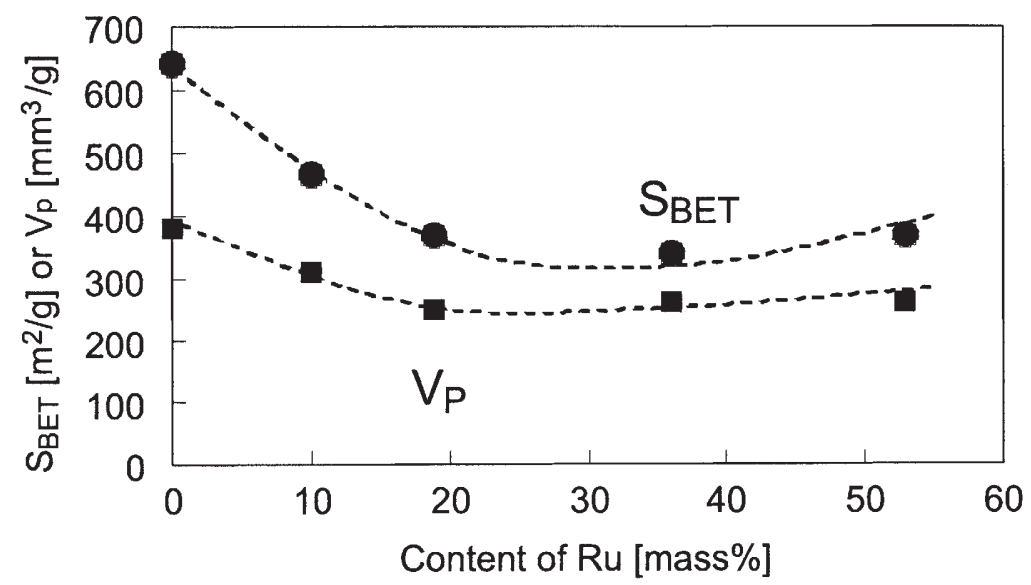

Fig.4 Effect of Ru content on specific surface area and pore volume of the activated Ru-Carbon composites.

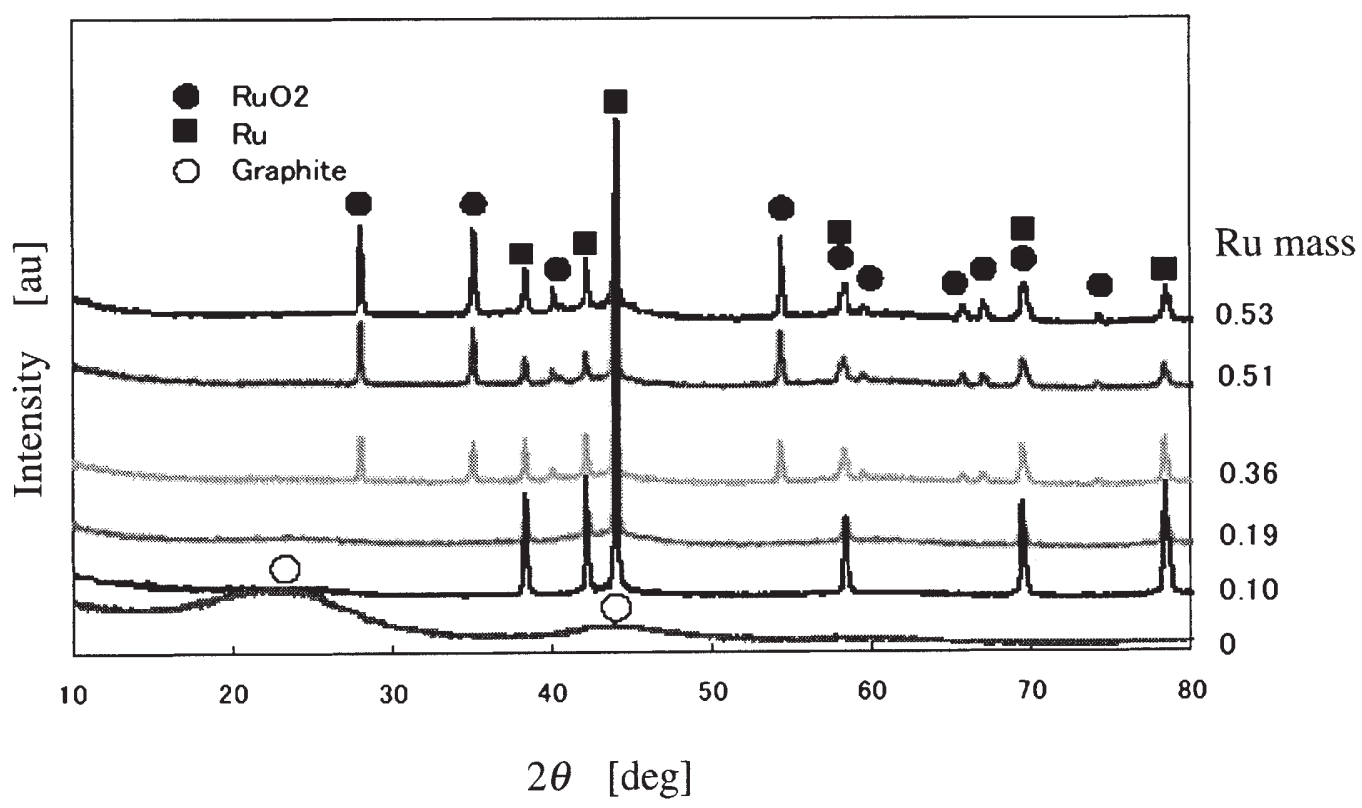

Fig.5 XRD pattern of the carbonized samples.

3.3 賦活物の XRD 解析

各賦活物のXRDパターンを Fig.5に示す. 図中の右端の数 値は賦活物中のルテニウム化合物の含有率を表している.
$\mathrm{Ru}^{3+}$ を吸着していない樹脂から得た賦活物の XRD パターン には炭素の乱層構造に対応するブロードなピークが観察され た. $\mathrm{Ru}^{3+}$ を吸着させて炭化・賦活した場合は, ルテニウム化 
合物の含有率が 0.10 および 0.19 のうに小さい場合, 賦活物 中に存在する結晶性のルテニウムは金属ルテニウムであるこ とがわかった．さらにルテニウムの含有量が大きくなり， 0.36 以上の含有率では酸化ルテニウム $\left(\mathrm{RuO}_{2}\right)$ が生成している ことがわかった，ルテニウムの価数に着目すると, 熱処理前 の $\mathrm{Ru}^{3+}$ が 3 ，金属ルテニウムが $0, \mathrm{RuO}_{2}$ では 4 であることか ら, 還元剂として作用する炭素がルテニウムに比べて多いと き(すなわちルテニウム含有量が小さいとき)，ルテニウムは 0価まで還元される．逆にルテニウム含有量が多くなり炭素 の相対量が減少すると, 還元されないルテニウムが多くなり イミノ二酷酸基の酸素と反応して $\mathrm{RuO}_{2}$ が生成するものと思 われる.このことはキレート樹脂やイオン交換樹脂が吸着し ているイオンの量の多少で還元雾囲気と酸化雾囲気を制御す ることを意味しており，金属化合物の生成に重要な反応場を 提供していることがわかる.これらのXRDパターンについて ルテニウム金属および $\mathrm{RuO}_{2}$ の結晶子径をScherrerの式より算 出したところ, いずれも $30-33 \mathrm{~nm}$ 程度でありルテニウム含 有量の影響を受けずほぼ一定であった。

3.4 キャパシ夕特性

\subsubsection{Ru - 炭素複合材}

種々のルテニウム含有量の炭素をキャパシタ電極として用 い充放電を繰り返し行い, 各放電曲線から求めた比静電容量 をFig.6に示す.ルテニウムを含まない電極を用いた場合の静 電容量は約 $40 \mathrm{~F} / \mathrm{g}$ であった。ルテニウム含有量が増えると静 電容量は小さくなる傾向を示した.ルテニウム含有率が小さ い場合, 先に示したXRDパターンではルテニウムは金属とし て存在することを示した. 金属ルテニウムはキャパシタの静 電容量に寄与しないので, その分, 質量基準の比静電容量之 して低下したと考えられる。しかし，ルテニウム含有率が， 0.10,0.19, ではほぼ同じ，0.36もわずかに低いがほぼ同じ静
電容量であることは, ルテニウムの含有率が高くなると, 静 電容量の向上に寄与する酸化ルテニウムが生成すること, お よびそのルテニウムが電解液と接触する割合が増えることな どの要因が影響しているものと思われる.ルテニウム含有量 がさらに大きくなって 0.51 になると, 静電容量は明らかに向 上し, 0.53 では静電容量は $50 \mathrm{~F} / \mathrm{g}$ に近い数值を示した.この ことは炭素質中に存在する酸化ルテニウムが擬似容量を発生 して静電容量に大きく奇与しているためである. キャパシタ 特性に寄与しないと思われる金属ルテニウムも電気化学的に 酸化処理すれば酸化ルテニウムに変換でき, 炭素一ルテニウ ム複合材として含有されるルテニウムを有効に使えると予想 される.

3.4.2 $\mathrm{RuO}_{2}$ と炭素混合材

次に本方法で調製した炭素一ルテニウム複合材の特徴を明 らかにするため, 炭素材料と市販の酸化ルテニウムの粒径を 揃え，物理的によく混合してキャパシタ電極として用い，充 放電実験を行った. 種々の割合で混合して調製した電極の静 電容量を Fig.7に示す. 酸化ルテニウムの含有率は, (1) 100 , (2) 0.91 , (3) 0.75 , (4) 0.5 , (5) 0.25 , (6) 0.17 , (7),(8) 0 である. 明 らかに酸化ルテニウムの含有率が増えるにつれ, 静電容量は 減少した.このことは酸化ルテニウムが単純な物理混合では キャパシタの静電容量に寄与しにくいことを示唆している. 酸化ルテニウム自身が電気伝導性が小さく電極にならないの で炭素粉体と接触しなければならないことおよび粒径が大き く酸化ルテニウムの電気化学反応が起こりにくいことが原因 と考えられる.

ルテニウム含有量と静電容量の関係をFig.8に示す. 炭素材 と酸化ルテニウムを物理的に混合した場合はルテニウムの含 有量が増えるにともに静電容量は直線的に減少した。これに 対し, 本方法で調製した炭素一ルテニウム複合材は, ルテニ

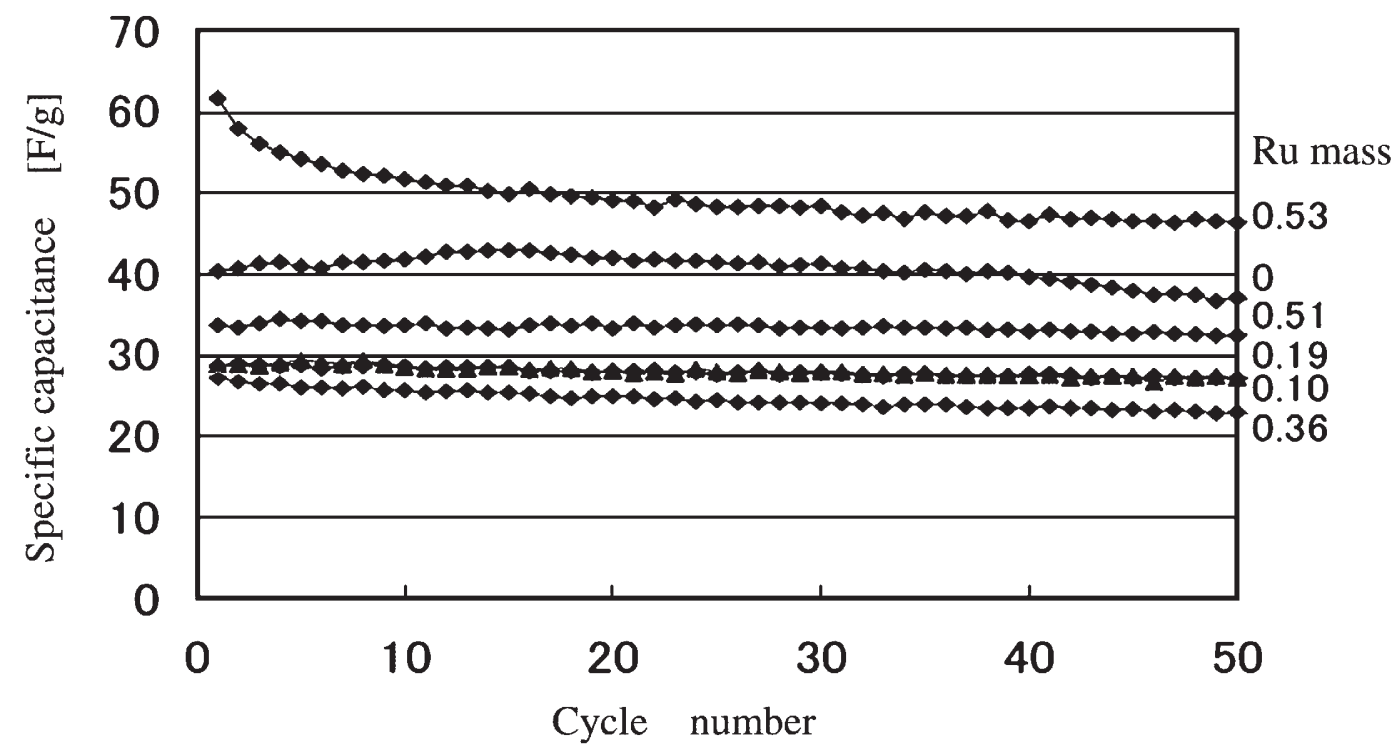

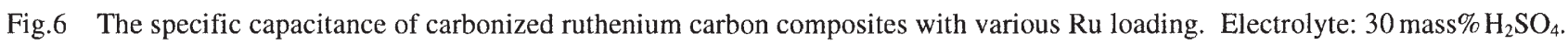




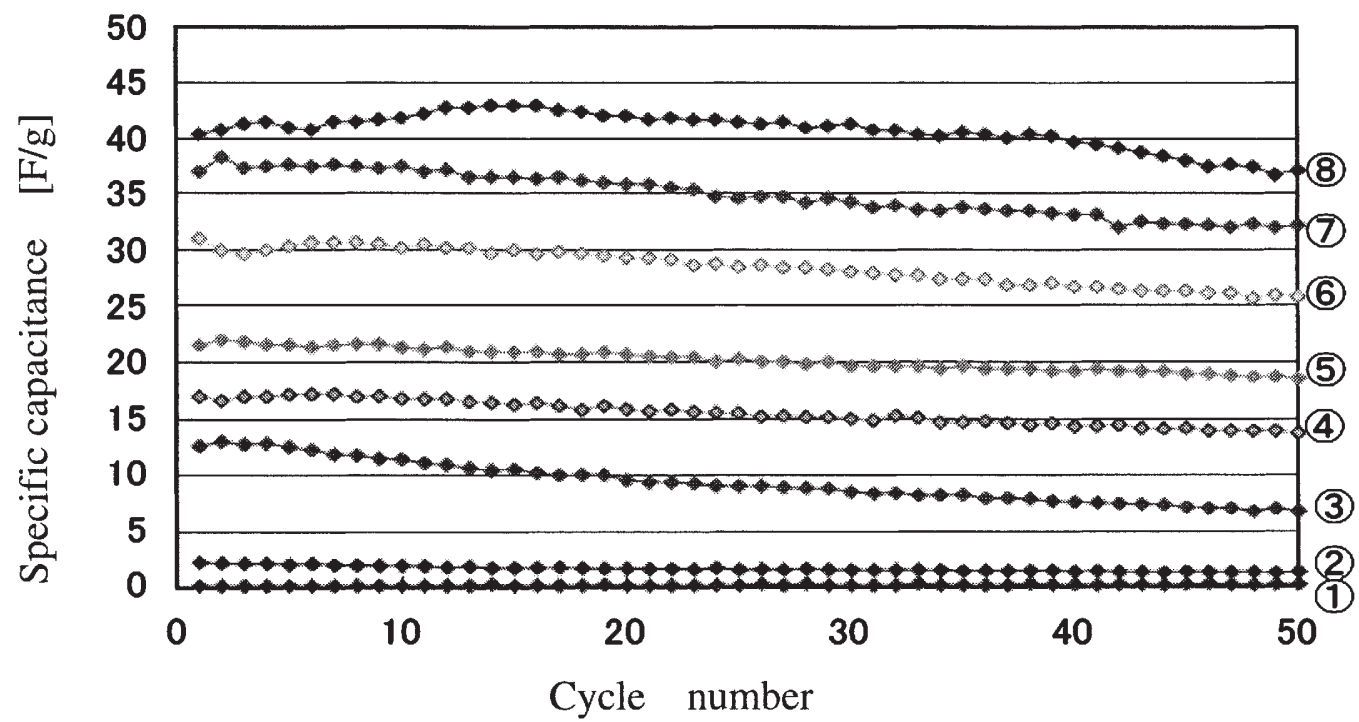

Fig.7 Specific capacitance of electrode prepared by physical mixing of ruthenium oxide and carbonaceous IRC748-Ru ${ }^{3+}$. Electrolyte: 30 mass $\% \mathrm{H}_{2} \mathrm{SO}_{4}$.

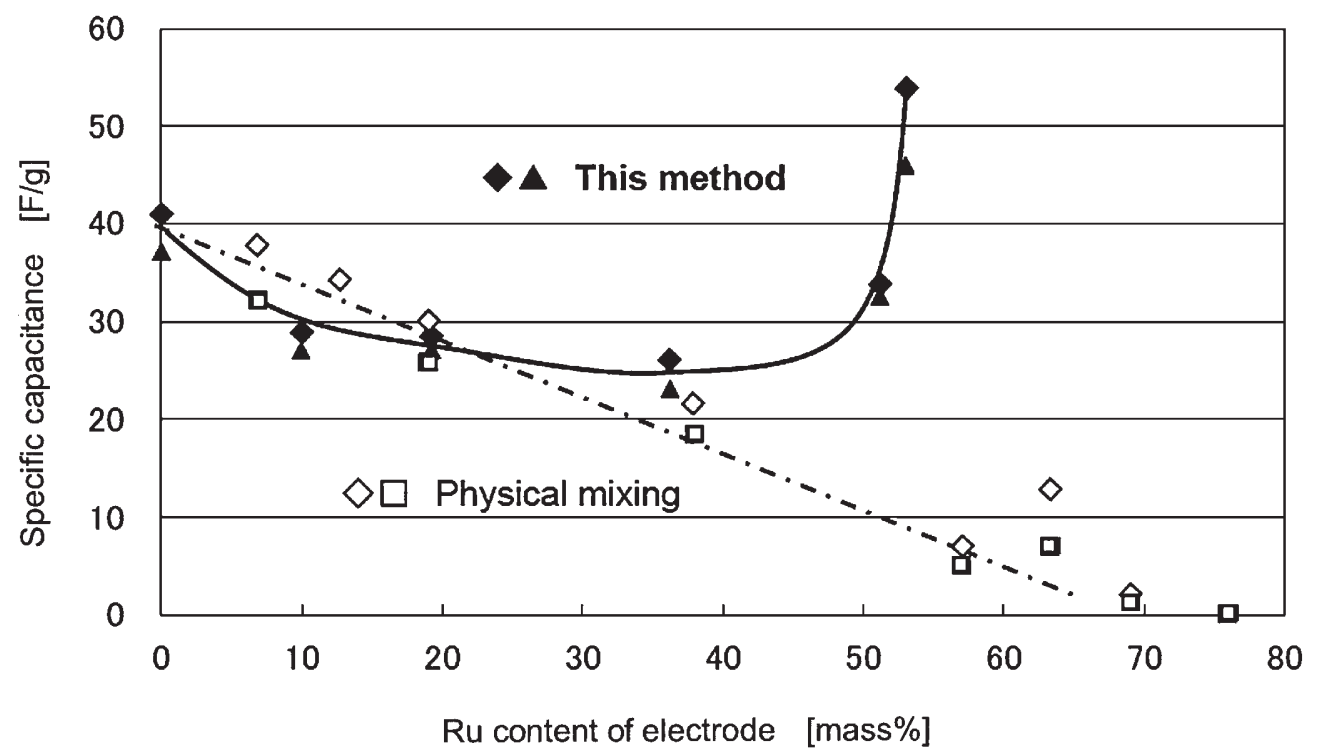

Fig.8 Effect of Ru content of electrode on specific capacitance.

ウムの含有量が小さい場合, 物理混合の場合と同様に静電容 量が減少した。しかし，その減少の仕方は物理混合に比べる といくぶん小さく, ルテニウム含有量が 0.36 以上では逆に大 きくなり，0.5付近では急激に増加した．これは本方法により 調製された酸化ルテニウムが炭素質中に微粒子としてよく分 散することにより, 各粒子が炭素とよく接触し電極として作 用すること, また, 炭素細孔に浸透した電解液と効率よく接 触し電気化学反応が起こることに適しており，キャパシタの 電極として好適であることを示唆している. 特にルテニウム 含有率が高い炭素一ルテニウム複合材については, 酸化ルテ
ニウム同土が炭素質と隣接しつつ細孔表面から電解液に露出 しやすい構造となり,ルテニウム含有量の増加に対し静電容 量が大きく向上したと思われる.

\section{4 結 言}

本研究では $\mathrm{Ru}^{3+}$ を吸着させたキレート樹脂を熱処理したル テニウムー炭素複合材を調製し, キャパシタ電極として詊価 した. また, 炭素多孔体と $\mathrm{RuO}_{2}$ の物理的混合物をキャパシタ 電極として評価し比較した. 以上の結果から以下のことがわ かった。 
(1) キレート樹脂にルテニウムイオンを吸着後, 賦活するこ とで，ルテニウム化合物微粒子が含まれる炭素材を調製 することができた.また, ルテニウムの含有量が大きい炭 素材は $\mathrm{RuO}_{2}$ も共存していることが明らかになった.

(2) ルテニウムー炭素複合材料のキャパシタ特性は低濃度吸 着量の場合, ルテニウムの未吸着炭素材より静電容量が 低くなり, 高濃度吸着量の場合では, 擬似容量の寄与が大 きくなり静電容量は高くなった.

(3) 物理的な混合材料は, 擬似容量の効果が見られず, $\mathrm{RuO}_{2}$ の含有量の上昇に伴い静電容量は下がった. 非伝導体で ある $\mathrm{RuO}_{2}$ がキャパシタとして擬似容量を発現せず, 容量 低下を促していると示唆される。

\section{謝辞}

炭素原料としてキレート樹脂をオルガノ株式会社よりご提 供いただいた。記して謝意を表します。

\section{文献}

1) B.E.Conway: "Transition from "Supercapacitor" to "Battery" Behavior in Electrochemical Energy Storage", J. Electrochem. Soc, 138(1991)1539-1548.

2) Y.Takasu, C.Matsuo, T.Ohnuma, M.Ueno and Y.Murakami: "Extremely High Pseudo-Capacitance of $\mathrm{RuO}_{2}$ Highly Dispersed on Glassy Carbon", Chem. Lett., (1998)1235-1236.

3) M.Wohlfahrt-Mehrens, J.Schenk, P.M.Wilde, E.Abdelmula P.Axmann and J.Garche: "New materials for supercapacitors", J. Power Sources, 105(2002)182-188.
4) Y.Takasu: Shingata kyapasita 3. Kagakusousetsu, 49, Nihonkagakukai, (2001)226-229.

5) Y.Sakata, A.Muto, Md. Azhar Uddin and K.Harino: "Modified Carbothermal Reduction for the Synthesis of Ultra Fine Particle Tungsten Compounds Dispersed in a Microporous Carbon Matrix", Journal of Materials Chemistry, 6(1996)1241-1243.

6) A.Muto, K.Ida, T.Baskar, Md.Azhar Uddin, S.Takashima, T.Hirai and Y.Sakata: "Preparation of Nevel $\mathrm{TiP}_{2} \mathrm{O}_{7}$ Carbon Compoiste Using Ion Exchange Resin (C467) and Evaluation for Photocatalytic Decomposition of 2- Propanol", Applied Catalysis A: General, 260(2004)163-168.

7) A.L.Patterson: "The Scherrer Formula for X-Ray Particle Size Dermination", Physical review, 56(1939)978-981.

8) Y.Sakata, A.Muto, Md.Azhar Uddin, N.Yamada, C.Marumo, S.Ibaraki and K.Kojima: "Preparation of a carbon electrode for an electric double layer capacitor (EDLC) from carbonization of a metal ion exchanged resin", Electorchemical and SolidState Letters, 3(2000) 1-3.

9) A.Muto, T.Bhaskar, Y.Kaneshiro, Y.Sakta, Y.Kusano and K.Murakami: Preparation: "Characterization of Nanocrystalline $\mathrm{CeO}_{2}-\mathrm{ZrO}_{2}$ Catalysts by Dry Method: Effect of Oxidizing Conditions", Applied Catalysis A General, 275(2004)173-181.

10) A.Muto, T.Bhaskara, Y.Kaneshiro, Md.Azhar Uddin, Y.Sakata, Y.Kusano and M.Kazuyuki: "Utilization of Waste Biomass and Replacement of Stoichiometric Reagent for the Syntrhesis of Nanocrystalline $\mathrm{CeO}_{2}, \mathrm{ZrO}_{2}$ And $\mathrm{CeO}_{2}-\mathrm{ZrO}_{2}$ ", Green Chemistry, 5(2003)480-483 . 